\title{
Producing Ceramic Water Purifiers Made Of Iraqi Bentonite Type (Bpl1)
}

\author{
Sanaa A. Jassim* \\ Riyadh Z. Al Zubaidy** \\ Habib Rashid Habib ${ }^{* * * *}$
}

Received 20, December, 2012

Accepted 11, March, 2014

\begin{abstract}
:
In this study, ceramic purifier (CP) was produced from a mixture of Iraqi raw materials. This ceramic mixture was prepared using Bentonite as a Clay, Porcelanite as a Silica, and Limestone as a flux. The produced ceramic filter was formed by semidry compressing method and was fired at $1200 C^{\circ}$.

Physical properties of the produced $\mathrm{CP}$ were measured. A hydraulic test rig was constructed to study the hydraulic conductivity of the produced $\mathrm{CP}$. The average hydraulic conductivity of the produced $\mathrm{CP}$ was 55 times that of commercial types of ceramic filters.

The mineral composition of the produced ceramics was found by X-Ray tests. Tests results showed that all of the produced ceramics filters composed mainly of low Cristobalte and Tridoymite in addition to some of other minerals.

Both of the raw and the water purified by produced ceramic were tested for a number of water quality parameters. that the ceramic disc purifier could remove, as an average percentages of removal, $99.98 \%$ of turbidity, $78.86 \%$ of the electrical conductivity, $81.61 \%$ of the total dissolved solids, $73.45 \%$ of $\mathrm{Ca}^{++}, 49.69 \%$ of $\mathrm{Na}^{+}$, $55.63 \% \mathrm{NO}_{3}^{-}, 37.54 \%$ of $\mathrm{HCO}_{3}{ }^{-}$.

The results showed that $\mathrm{CP}$ has excellent adsorption ability for solutes of seven heavy metals, $\mathrm{Mn}, \mathrm{Fe}, \mathrm{Pb}, \mathrm{Cd}, \mathrm{Co}, \mathrm{Cu}$ and $\mathrm{Zn}$, at concentrations of $1 \mathrm{mg} /$ each and 10 $m g / l$ each. The adsorption capacities of each filter to adsorb seven heavy metals were computed according to Langmuir model and Freundlich models. The results showed variety in adsorption capacities for each heavy metal.
\end{abstract}

Key words: Ceramic, purifiers, Bentonite, Adsorption, Heavy metals.

\section{Introduction:}

Water filtration means removing undesirable contaminates such as suspended solids, dissolved salts, microorganism, and other chemical substances from contaminated water. Filtration is done by passing water through a medium that allows only water with a quality that meets water standards of a specific purpose to pass through. Water filtration is a very important subject due to lack of water in some regions that require circulation and reuse of water.
Ceramic is produc by firing materials or mixture of materials of inorganic and non-metallic materials. Its properties can be controlled by developing technology to meet certain purposes. The pore size of the ceramic material can be made homogeneous and small within the range of microfiltration, which is excellent to remove most of the suspended solids and bacteria. Some of particles smaller than the ceramic pore size could be adsorbed by ceramic. CP can withstand solutions of high temperatures and a

*civil Dept., Technical Institute of Babylon.

**Dept.of Water Resourses, College of Engineering, Baghdad University.

***Dept. of Geology, College of Science, Baghdad University. 
wide range of acidity that other microfiltration media can't withstand. $\mathrm{CP}$ can be operated with a proper maintenance or stored for a long time without losing its filtration efficiency. $\mathrm{CP}$ can be used easly and they have no side effects, they are environmentally friendly.

Generally, this research aims to study the hydraulic performance and adsorption propert of the $\mathrm{CP}$ made of local materials.

\section{Laboratory Work}

Laboratory work of this study includes preparing raw materials, producing the ceramic, and the necessary test to get the physical and purification properties of the ceramic product.

\section{Preparing Raw Materials And Producing Cp}

The ceramic raw materials that are used in this study are: Bentonite, Porcelanite, and

Limestone. They were provided by

General Company of Geological

Surveying and Mineralization. Table 1 showes the chemical analysis of raw materials.

Bentonite is one of the clay minerals in Iraq[ 1]. It is composed of the following minerals: Montmorillonite, with $80 \%$ Alumino-Calcium Silicates[ 2]. It consists of one sheet of AluminoSilicates with varying water content and a little of Alkalis $\mathrm{Mg}_{2} \mathrm{Al}_{10} \mathrm{Si}_{24} \mathrm{O}_{60}(\mathrm{OH})_{12} \mathrm{Ca}$, [ 2]. Due to its structure it has high ion exchange capacity, 80-150meq/gm, [ 3], as reported in[1].

Porcelanite is a siliceous rock. These rocks are found in Iraq in Akashatat the western

desert. It is largely composed of sponge spicules and some other siliceous microfossils (Diatoms and Radiolarian), as well as silicified foraminifera and non-plankton, [ 4]. It is composed of the following minerals: Cristobalite, Tridymite, and Calcite, [ 2].

Limestone is a white rock found at

Kerbela and the western desert in Iraq.

It is mainly composed of Alcalsiet, $\mathrm{CaCO}_{3},[2]$.

Table 1. Chemical analysis of raw materials.[2]

\begin{tabular}{|c|c|c|c|c|c|c|c|c|}
\hline Compound & $\mathrm{SiO}_{\mathbf{2}}$ & $\mathrm{Al}_{2} \mathbf{O}_{\mathbf{3}}$ & $\mathrm{Fe}_{\mathbf{2}} \mathbf{O}_{\mathbf{3}}$ & $\mathbf{C a O}$ & $\mathbf{T i O}_{\mathbf{2}}$ & $\mathbf{M g O}$ & $\mathbf{N a}_{\mathbf{2}} \mathbf{O}$ & L.O.I \\
\hline Bentonite & 56.5 & 15.5 & 5.3 & 4.5 & 0.6 & 3.5 & 0.7 & 10 \\
\hline Porcelaniet & 75.3 & 1.95 & 0.77 & 4.6 & 0.11 & 4.7 & 0.1 & 8.5 \\
\hline Limstone & 3.16 & 0.12 & 0.22 & 54.04 & 0.02 & 0.67 & 0.38 & 41.74 \\
\hline
\end{tabular}

Raw materials were milled and sieved to be uniformly graded material to get porous ceramic, [ 5] as reported in[ 6]. Generally, Clay plus Silica and fluxes are used to produce ceramic. Bentonite, as a clay, Porcelanite as a Silica, and Limestone as a flux were used in this study. The creamic mixtures were used depending on the weight of the component used to the total weight of the mix used to produce the ceramic samples. Bentoniet formed the large ratio in the ceramic mixture contains comparable to the other component.

Mixtures were prepared by semi dried compressing method with $10 \%$ by weight of water content [ 7].

CP samples were manufactured in this study as cylindrical disc tablets of a diameter of $50 \mathrm{~mm}$ and thickness of 10 $m m$, using semi drypressing method, Fig.1. Carbonate steel mold was manufactured to produce the ceramic 
discs as shown in Fig. 2. The mold should be cleaned and lubricated by thin oil (glycerin) before each pressing, [6].

Some of the prepared wet mixture was placed in the mold and pressed with an electrical hydraulic jack at $250 \mathrm{~kg} / \mathrm{cm}^{2}$, Drying the sample at $105 C^{\circ}$ for $24 h r$, .

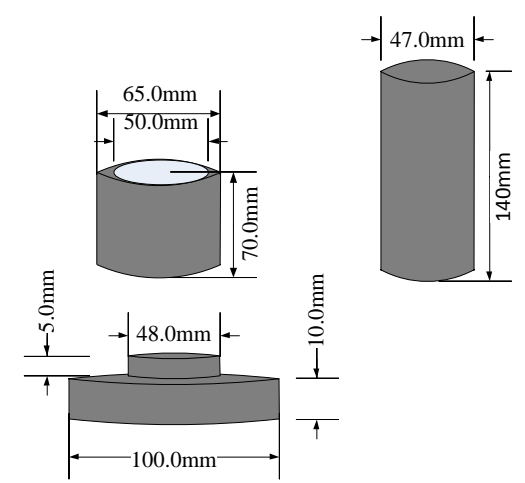

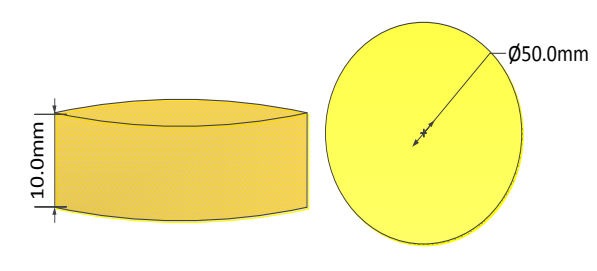

Fig.1- Filter Ceramic Disc Dimensions

Fig.2. Manufactured Carbonate Steel Mold.

The firing process of the dry discs, previously prepared, was carried out at at $1200 C^{o}$.

The firing was done by electrical muffle furnace. Three ceramic discs were produced. These discs were shown in Fig. 3.

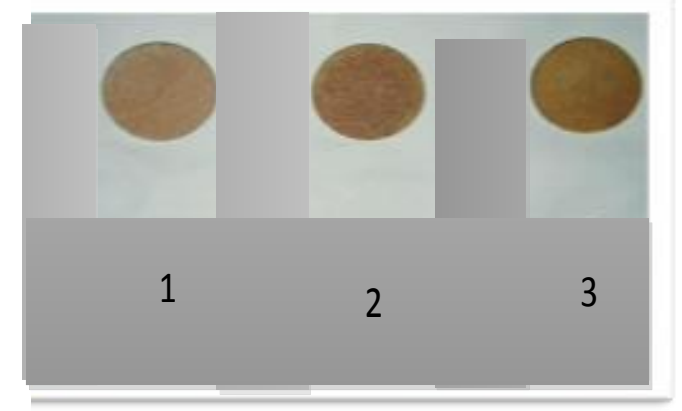

Fig.3. The Produced Ceramic Discs.

\section{PHYSICAL TESTS}

Tests were carried out to examine the physical properties of the produced ceramic discs. The physical properties which may affect the durability and hydraulic conductivity of ceramic are the apparent density, and porosity.

Density and Porosity Tests

Apparent density means dry density. It affects the compressive and tensile strength of ceramic. It also gives the indication to the porosity of ceramic. Apparent density of ceramic body depends on firing program, size graduation, applied pressure and water content during shaping process, [ 8].

Porosity refers to the percentage of pore space in a material. An open pore is a cavity or

channel that communicates with the surface of the particle.

The apparent density, apparent and true porosity of ceramic discs were measured according to ASTM-C 373 standards, [ 9].

\section{Hydraulic Conductivity Test}

The hydraulic conductivity(HC) of a porous medium defines its ability to transmit

water. It can be defined as the rat of flow per unit area of porous medium, which is perpendicular to the direction of flow, under unit hydraulic gradient. It has units of velocity $(\mathrm{cm} / \mathrm{sec}, \mathrm{cm} / \mathrm{min}$, $m / h r$, and $m / d a y)$, [ 10]:

$$
H C=\frac{q}{i}
$$


where: $H C=$ hydraulic conductivity, $\mathrm{cm} / \mathrm{sec}, \mathrm{cm} / \mathrm{min}, \mathrm{m} / \mathrm{hr}$, and $\mathrm{m} / \mathrm{day}, q=$ rat of water flow per unit cross sectional area, $\mathrm{m}^{3} / \mathrm{m}^{2} \mathrm{hr}$, and $i_{h}=$ hydraulic gradient.That is, [10]:

$$
i_{h}=\frac{\Delta h}{\Delta l}
$$

where $\Delta h=$ loss in hydraulic head through flow path, $m$, and $\Delta l=$ length of flow path, $m$.

The hydraulic conductivity is calculated by constant head method by applying the

following equation, [10] :

$K=\frac{Q \times L}{A_{c} \times t \times h}$

Where: $\mathrm{A}_{\mathrm{c}}=$ cross section area of ceramic sample, $m^{2}, h=$ constant head exerted by water level, $m, L=$ length of sample, $m, Q=$ water discharge passed $\mathrm{CP}$ at time $t, \mathrm{~m}^{3}$, and $t=$ time at which water discharge $Q$ passed through $\mathrm{CP}$. Constant head method was employed to measure $\mathrm{K}$ of the whole ceramic disc production using distilled water. Equipment was designed to be used for measuring hydraulic conductivity Fig. 4 shows the general view of the hydraulic conductivity equipment that was constructed to be used to measure $\mathrm{K}$ described by equation 3. Fig. 5 shows a schematic diagram of the equipment. The equipment consists of a plastic or glass tube with a $52 \mathrm{~mm}$ diameter and $150 \mathrm{~mm}$ height in which the ceramic disc was fixed inside it and sealed with silicon to prevent water from passing through the open between tube and ceramic disc. The tube placed between two galvanized steel covers containing valves for inlet and outlet water. Control of the head of water above the filter was arranged using a loop system. The equipment set-up for hydraulic conductivity Investigations is detailed below:

The reservoir which provided the head above the filter disc consisted of an opaque polyethylene cylinder of
$250 \mathrm{~mm}$ in diameter and a height of $250 \mathrm{~mm}$. The cylinder containing 50 $\mathrm{mm}$ tube inside it to keep the water in the reservoir at a constant head, which is called, overflow tube. The overflow water from the overflow tube is discharged to other reservoir, which is inlet reservoir. Influent flow to the head reservoir was drawn from an inlet reservoir using a pump. This maintains slow flow rates whilst not physically contacting the influent water. Thus head was controlled at a constant level, allowing water loss from the system as it filtered through the ceramic. The test collection placed at an aluminum frame in order to raise the head reservoir to the desired head. Fig. 6 shows the test set up view and Fig.7 shows a schematic diagram of the test set up.

Each test of $\mathrm{HC}$ of the ceramic disc test was carried out with one replication. Computing the average saturated hydraulic conductivity $H C_{a}$ for each disc. Computing the standard hydraulic conductivity, $H C_{s}$, for each disc according to equation, [11]:

$$
H C_{s}=H C_{\alpha} \frac{\mu}{\mu 20}
$$

where: $\quad H C_{a}=$ average saturated hydraulic onductivity, $m h r, \mu=$ viscosity of water at any temperature, $P a . s$, and $\mu_{20}=$ viscosity of water at $20^{\circ} \mathrm{C}, P$ a.s.

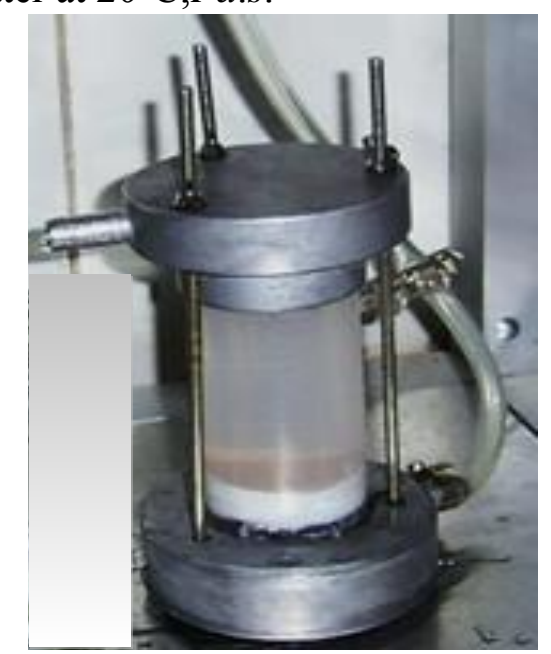

Fig. 4. General view of hydraulic conductivity test equipment. 


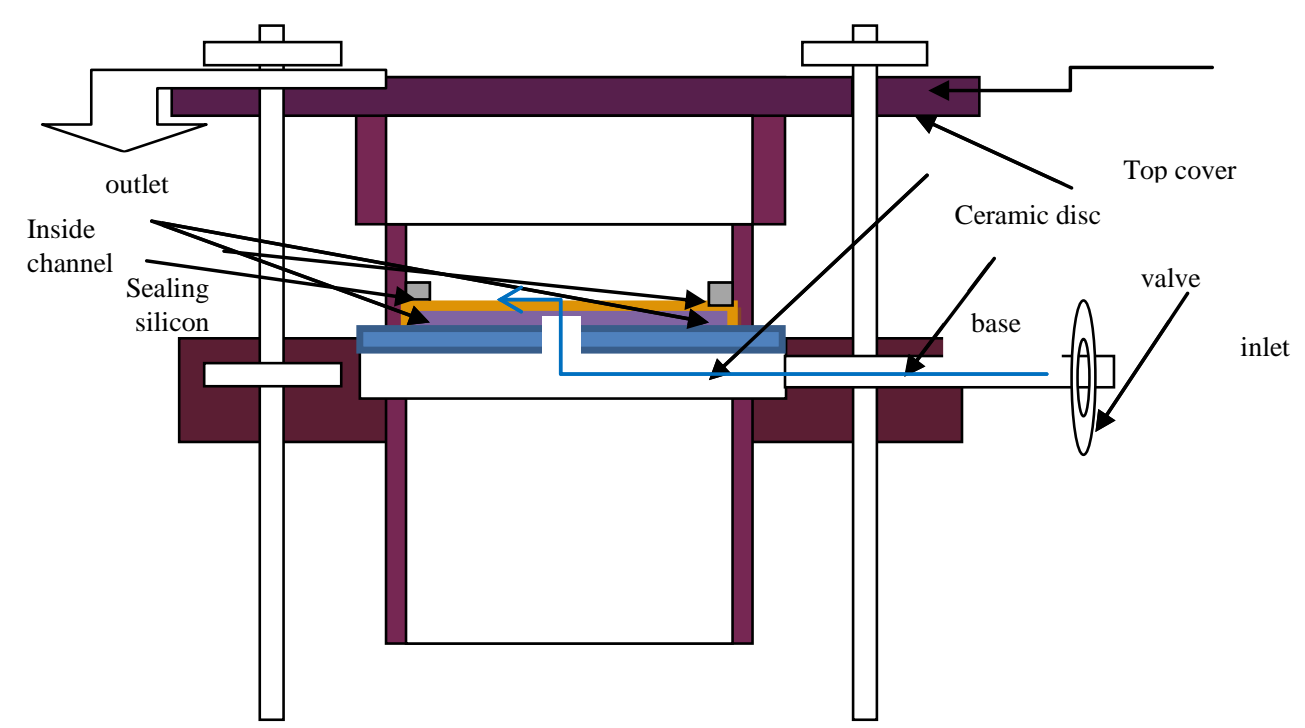

Fixing screws

Fig. 5. Schematic diagram of hydraulic conductivity test equipment.

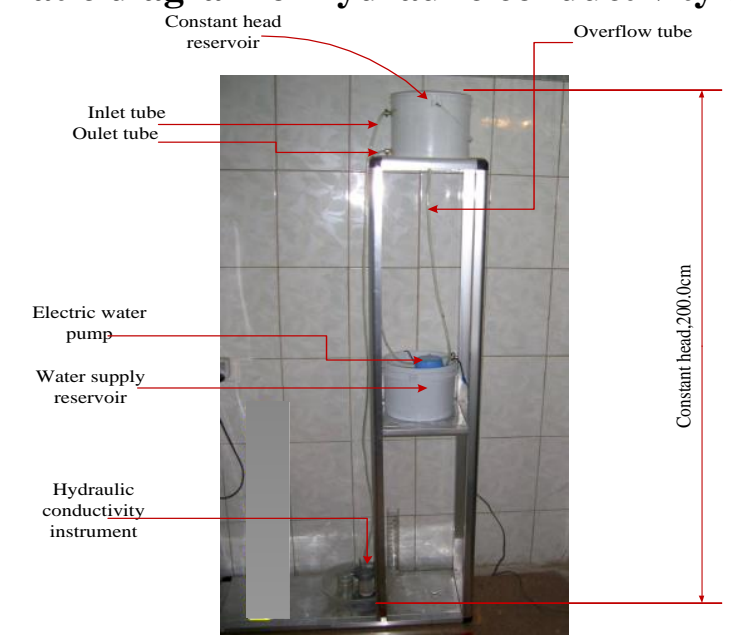

Fig. 6. General View of hydraulic conductivity test rig.

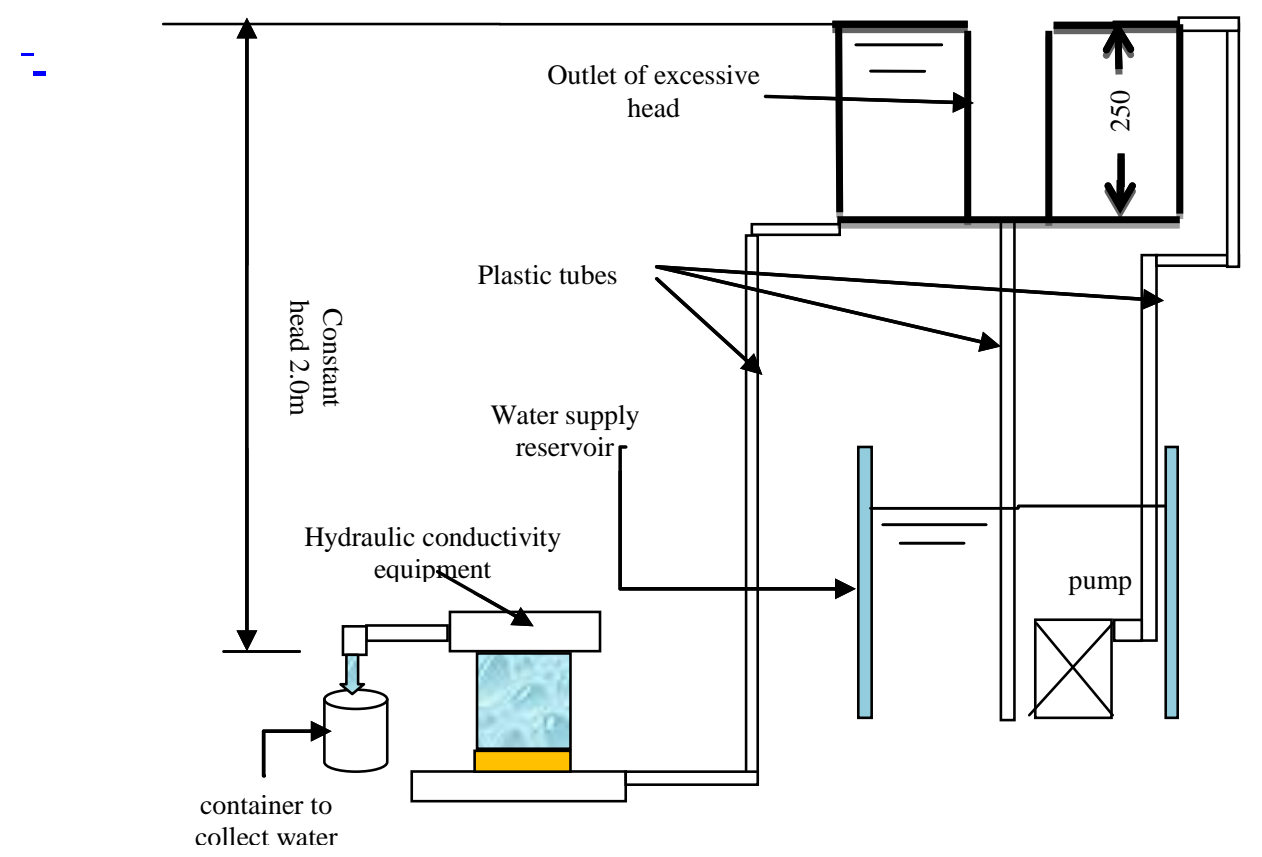

Fig.7. Schematic diagram of hydraulic conductivity test rig. 


\section{Mineralogical Tests \\ Mineralogical tests of the produced ceramic discs were done by the X-ray reflection device at Baghdad University College of Science Geological Department x-ray laboratory, [12]. The samples were tested in Philips X-Ray Powder Diffractometer Vertical Gionometer PW 1050/10.}

\section{Adsorption Test}

Adsorption test was carried for each produced ceramic disc.The test was carried out

passing polluted water through the ceramic disc and measuring the concentration of pollution

before and after passing. The polluted water was prepared at laboratory. 500 $m g /$ standard stock solutions of $\mathrm{Pb}$ (II), $\mathrm{Co}(\mathrm{II}), \mathrm{Fe}(\mathrm{II}), \mathrm{Mn}$ (II), Cd(II), Zn(II)and $\mathrm{Cu}(\mathrm{II})$ were prepared as follows:

The required amount of metal salt was dissolved into one liter of distilledwater and

stirred. Mass of metal salt was calculated as follows: $500 \mathrm{ppm}=500$ $m g$ /.To make one liter of metal salt solute, $500 \mathrm{mg}$ metal is needed, $0.50 \mathrm{~g}$ of metal. That means, [13]:

$M a=0.5$ (g. of metal $) \times \frac{M W}{A W}$

where: $M a=$ mass of metal salt, $g, M W$ $=$ molecular weight of the metal salt, $g$, and $A W=$ atomic weight of metal in salt, $g$.

Make up solutions of $\mathrm{Pb}(\mathrm{II}), \mathrm{Co}(\mathrm{II})$, $\mathrm{Fe}(\mathrm{II}), \mathrm{Mn}(\mathrm{II}), \mathrm{Cd}(\mathrm{II}), \mathrm{Zn}(\mathrm{II})$, and $\mathrm{Cu}(\mathrm{II})$ at different

concentratio1,10, 20,40,60, and 80 $m g /$ of each of these ions by diluting $0.2,2,4,8,12,16$, and $20 \mathrm{ml}$ of the $500 \mathrm{mg} /$ standard solution to100 $\mathrm{ml}$, with distilled water [ 6].

Adsorptiontest was carried out at room temperature. The test was carried out for all filters together at one time. The final concentrations of metal ions in the solution were determined by atomic absorption spectrometer, AAS, for residual metal content. The percentage adsorption was calculated as follows, [13]:

$$
A P=\frac{C_{o}-C_{B}}{C_{0}} \times 100
$$

where: $A p=$ percentage of adsorption, $\%$. Co =initial concentration of metal ion in the queous phase, $m g /, \mathrm{Ce}=$ final concentration of metal ion in the aqueous phase, $m g /$.

\section{Adsorption capacity}

Two of the more common mathematical formulations used in establishing

adsorption isotherms are the Freundlich and Langmuir equations.

The Langmuir Isotherm

One particular mathematical form of an isotherm which is often found to fit experimental data is the so-called Langmuir isotherm [14], which was derived in 1916 by Irving Langmuir [15]. The Langmuir equation applicable to adsorption is described as [13]:

$$
\mathrm{Ce} / \mathrm{qe}=1 / \mathrm{Q}_{\mathrm{o}} \mathrm{b}+\mathrm{Ce} / \mathrm{Q}_{\mathrm{o}}
$$

Where: $\mathrm{Ce}=$ the equilibrium concentration of the adsorbate $(\mathrm{mg} / \mathrm{L})$ in solution.

qe =the amount of adsorbate adsorbed per unit mass of adsorbent at equilibrium $(\mathrm{mg} / \mathrm{g})$.

$\mathrm{Q}_{\mathrm{o}}$ and $\mathrm{b}=$ Langmuir constants related to the adsorption capacity an energy of adsorption, respectively. When Ce/qe is plotted versus $\mathrm{Ce}$, the slope is equal to $1 / \mathrm{Q}_{\mathrm{o}}$ and the intercept is equal to

$1 / \mathrm{Q}_{\mathrm{o}} \mathrm{b}[16]$

\section{The Freundlich Isotherm}

Non-ideal systems can sometimes be fitted to an empirical dsorption isotherm developed by the German physical chemist Herbert Max Finlay Freundlich(1880-1941), [ 15] . The 
Freundlich equation applicable to adsorption is described as, [17]:

Log qe $=\log \mathrm{Kf}+1 / \mathrm{n} \log \mathrm{Ce}$

Where: $\mathrm{Ce} \quad$ the equilibrium concentration of the adsorbate $(\mathrm{mg} / \mathrm{L})$ in solution.

qe =the amount of adsorbate adsorbed per unit mass of adsorbent at equilibrium $(\mathrm{mg} / \mathrm{g})$.

Kf and $\mathrm{n}=$ constants incorporating all factors affecting the adsorption.

\section{Water Purification Tests}

Water is an essential resource for living systems, industrial rocesses, agricultural production and domestic use. The principal factors that are taken into consideration when determining water quality are, [18]: Turbidity, $\mathrm{PH}$, EC, TDS, $\mathrm{Ca}^{+2}, \mathrm{Mg}^{+2}, \mathrm{Na}^{+}, \mathrm{Cl}^{-}, \mathrm{HCO}_{3}{ }^{-}$, $\mathrm{SO}_{4}{ }^{-2}, \mathrm{NO}_{3}{ }^{-}$,

\section{Results and Discussion:}

This paragraph presents the laboratory experiments results that were carried out to examine the physical properties, hydraulic performance, and adsorability of the produced ceramic discs.

\section{Physical Properties}

Six tests were carried out to specify the physical properties of the produced CP discs. The results of physical properties tests are listed in Table 2.

Table 2: Average Physical Properties of Ceramic purifier.

\begin{tabular}{|c|c|c|c|}
\hline $\begin{array}{c}\rho_{a}, \text { apparent } \\
\text { density, } \mathrm{gm} / \mathrm{cm}^{3}\end{array}$ & $\begin{array}{c}n a, \\
\text { apparent } \\
\text { porosity }\end{array}$ & $\begin{array}{c}\mathrm{nt} \text {, true } \\
\text { porosity }\end{array}$ & $\begin{array}{c}w a, \% \\
\text { absorbed } \\
\text { water }\end{array}$ \\
\hline 1.43 & 48.10 & 15.3 & 33.68 \\
\hline
\end{tabular}

Hydraulic Conductivity Test

Hydraulic conductivity test was carried out on $\mathrm{CP}$, including three replications, to evaluate its hydraulic performance.

The tests were carried following the constant head method which was viewed previously.

The results showed that the average hydraulic conductivity was 0.0023 $\mathrm{m} / \mathrm{hr}$, which is 56.5 times maximum hydraulic conductivity of the commercially available ceramic filters which is about $0.00004 \mathrm{~m} / \mathrm{hr}$, [6].

\section{Mineralogical Test}

Mineralogical test was carried on the produced ceramic purifier according to the procedure explained befor. The resulting minerals were found by measuring their reflecting angles and their intensities as shown in Fig. 8, which showed the following:

Ceramic purifier which made of mixture of Bentonite, Porcelanite, and Limestone composed of Montmorilniet ((Ca,Na) $\mathrm{Mg}_{2} \mathrm{Al}_{10} \mathrm{Si}_{24} \mathrm{O}_{60}(\mathrm{OH})$ ), Low Cristobalite $\left(\mathrm{SiO}_{2}\right)$, Tridoymite $\left(\mathrm{SiO}_{2}\right)$, and Calcite $\left(\mathrm{CaCO}_{3}\right)$, respectively. These minerals transformed after burning to: Anorthite $\left(\mathrm{CaAl}_{2} \mathrm{Si}_{2} \mathrm{O}_{8}\right)$, Beta-Quartz $\left(\left(\mathrm{SiO}_{2}\right), \quad\right.$ Plagioclase$\operatorname{syn}\left(0.71 \mathrm{NaAlSi}_{3} \mathrm{O}_{3}, \quad 0.29 \mathrm{CaAl}_{2} \mathrm{Si}_{2} \mathrm{O}_{8}\right)$, and Protoenstatite $\left(\mathrm{MgSiO}_{3}\right)$. It could be seen that the three has of silica $\left(\mathrm{SiO}_{2}\right)$, Beta Quartz, Tridoymite, and Low Cristobalite, had appeared in this ceramic filter due to the same reasons mentioned before. While $\mathrm{Al}^{+3}$ appeared in Anorthite and Plagioclase syn in addition to some impurity with $\mathrm{Na}^{+}$. Protoenstatite $\left(\mathrm{MgSiO}_{3}\right)$ had appeared due to existing of some impurity of $\mathrm{Mg}^{+2}$ in the initial composition of minerals with plenty of silica in all used minerals, and it is stable phase of Magnesium Silicate which formed at high temperatures, [ 19] as reported in [6]. 


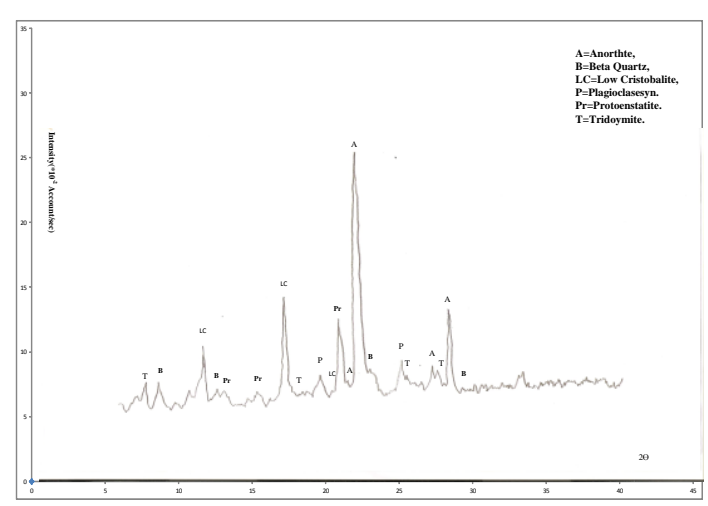

Fig. 8: X-Ray Diagram of ceramic disc filter.

\section{Heavy Metals Adsorption Tests}

Two adsorption tests, including two replication, were carried out to examine the adsorption of heavy metals properties of the produced $\mathrm{CP}$ disc. One, including one replication, were carried out on a per prepared solution of $1 \mathrm{mg} /$ of each of seven heavy metals, $\mathrm{Mn}, \mathrm{Fe}, \mathrm{Pb}, \mathrm{Cd}, \mathrm{Co}, \mathrm{Cu}$ and $\mathrm{Zn}$. Other one test, including one replication, were carried out on per prepared solution of $10 \mathrm{mg} /$ of each of these seven heavy metals.

According to Iraqi Specifications No 417 [ 20], limits of these heavy metals, $\mathrm{Mn}, \mathrm{Fe}, \mathrm{Pb}, \mathrm{Cd}, \mathrm{Co}, \mathrm{Cu}$ and $\mathrm{Znin}$ drinking waterare listed inTable 2.

Table 2. Iraqi specifications limits of heavy metals in drinking water.

\begin{tabular}{|l|l|l|l|l|l|l|}
\hline Heavy metal & $\mathrm{Pb}$ & $\begin{array}{l}\mathrm{C} \\
\mathrm{d}\end{array}$ & $\begin{array}{l}\mathrm{Z} \\
\mathrm{n}\end{array}$ & $\begin{array}{l}\mathrm{C} \\
\mathrm{u}\end{array}$ & $\begin{array}{l}\mathrm{F} \\
\mathrm{e}\end{array}$ & $\begin{array}{l}\mathrm{M} \\
\mathrm{n}\end{array}$ \\
\hline Concentration, & 0. & 0. & 1. & 0. & 0. & 0. \\
$m g /$ & 05 & 01 & 0 & 5 & 5 & 1 \\
\hline
\end{tabular}

Average results of test that were carried out to examine heavy metals adsorption

properties of the produced $\mathrm{CP}$ discs using a per prepared solution of $1 \mathrm{mg} /$ of each of the used seven heavy metals, $\mathrm{Mn}, \mathrm{Fe}, \mathrm{Pb}, \mathrm{Cd}, \mathrm{Co}, \mathrm{Cu}$ and $\mathrm{Zn}$, are shown in Fig.9. Generally, the results showed that CP adsorbed most of the heavy metals ions. The removal varies between $(99.60-100 \%)$ of the initial concentration.

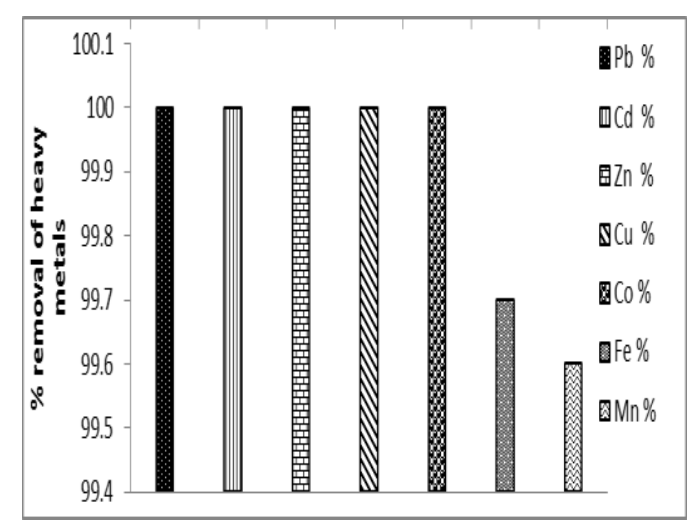

Fig 9: \% of removal of heavy metals at concentration $1 \mathrm{mg} / \mathrm{l}$.

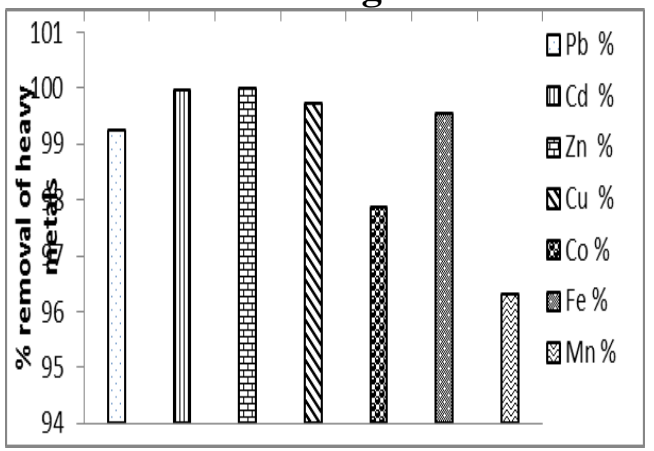

Fig 10: \% of removal of heavy metals at concentration $10 \mathrm{mg} / \mathrm{l}$.

Fig. 10 showed the average results of test that were carried out to examine heavy metals

adsorption properties of the produced $\mathrm{CF}$ discs using a per prepared solution of $10 \mathrm{mg} /$ of each of the used seven heavy metals, $\mathrm{Mn}, \mathrm{Fe}, \mathrm{Pb}, \mathrm{Cd}, \mathrm{Co}, \mathrm{Cu}$ and $\mathrm{Zn}$. Generally, the results showed that all the ceramic filters adsorbed most of the heavy metals ions. Fig. 10 showes the variation in percentages of adsorption of the heavy metals with 10 $m g / l$ concentrain of each of the produced ceramic. The adsorption varies between 96.32 and $100 \%$ of the initial concentration of each metal. Adsorption Capacity

Adsorption capacities of $\mathrm{CP}$, was measured according to the procedure mentioned befor.

The polluted water with seven heavy metals $(\mathrm{Mn}, \mathrm{Fe}, \mathrm{Pb}, \mathrm{Cd}, \mathrm{Co}, \mathrm{Cu}$, and $\mathrm{Zn})$, at $(20,40,60$, and $80 \mathrm{mg} / \mathrm{l})$ of each metal. The remaining 
concentrations (Ce $m g / l$ ) of these metals after passing through these filters were measured. Adsorption capacity (qe $m g$ of metal adsorbed by one gram of adsorbent) at each concentrate were calculated as mentioned. Then graphs were plotted according to both Langmuir and Freundlich methods which had explained befor. Langmuir and Freundlich graphs were plotted as shown in Figs. 11 for Cobalt adsorption data. The correlation coefficient $\mathrm{R}^{2}$ was 0.9411 for Langmuir graph and 0.9844 for Freundlich graph. The same thing was done for all adsorption data for each heavy metal adsorption and for each filter. adsorption capacity results were shown in Table 3. Results of adsorption capacities according to Freundlich model were: $\mathrm{Pb}>\mathrm{Cd}>\mathrm{Cu}>\mathrm{Zn}>\mathrm{Mn}>\mathrm{Co}>\mathrm{Fe}, \quad$ and maximum capacity was for $\mathrm{Pb}(3.694$ $m g / g)$, and minimum was for $\mathrm{Fe}(1.517$ $\mathrm{mg} / \mathrm{g}$ ). While the results according to Langmuir model were: $\mathrm{Fe}>\mathrm{Co}>\mathrm{Mn}>\mathrm{Zn}>\mathrm{Pb}>\mathrm{Cd}>\mathrm{Cu}, \quad$ and maximum capacity was for $\mathrm{Fe}(1.337$ $m g / g$ ), and minimum was for $\mathrm{Cu}$ (0.394 mg/g).
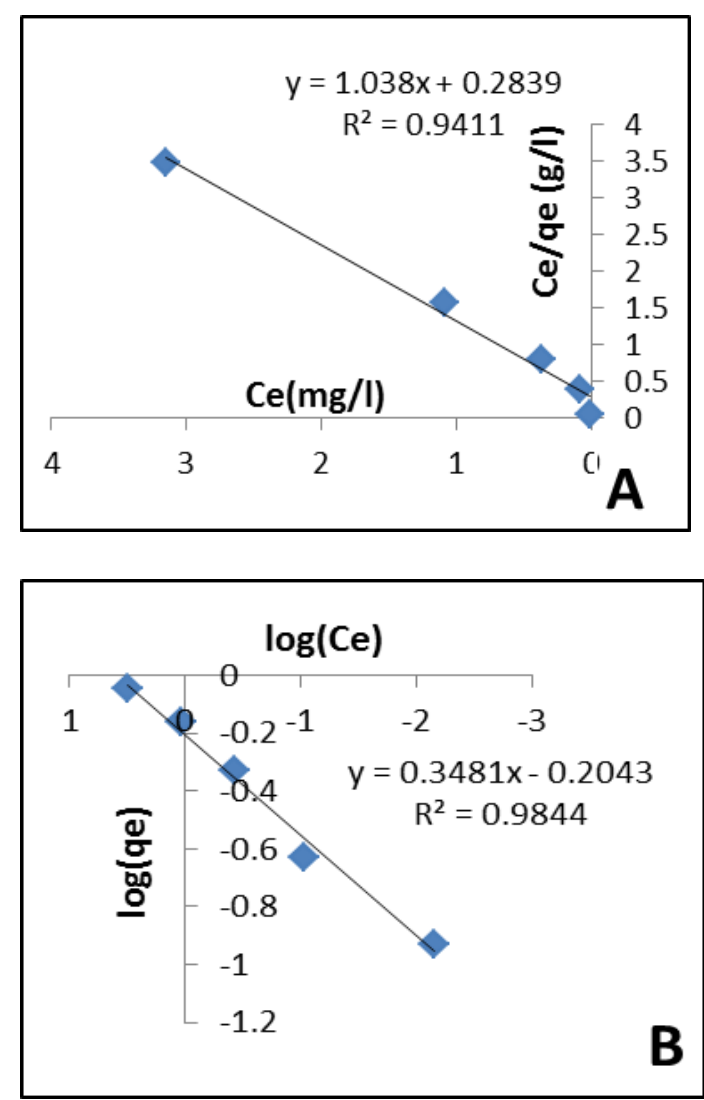

Figs.11.A: Langmuir graph,: Frundlich graph of data for adsorption capacity of $\mathrm{Co}$.

Table 3. Adsorption Capacities of Produced Filter for Seven Heavy Metals

\begin{tabular}{|c|c|c|c|c|}
\hline $\begin{array}{c}\text { metal } \\
\text { ion }\end{array}$ & $\begin{array}{c}\text { Adsorption } \\
\text { capacity(mg/g) } \\
\text { (Langmuir } \\
\text { model) }\end{array}$ & $\mathbf{R}^{\mathbf{2}}$ & $\begin{array}{c}\text { Adsorption } \\
\text { capacity } \\
\text { (mg/g) } \\
\text { (Freundlich } \\
\text { model) }\end{array}$ & $\mathbf{R}^{\mathbf{2}}$ \\
\hline $\mathbf{M n}$ & 1.176 & 0.9678 & 1.747 & 0.9716 \\
\hline $\mathbf{C u}$ & 0.394 & 0.8985 & 3.193 & 0.9891 \\
\hline $\mathbf{C o}$ & 1.305 & 0.9411 & 1.593 & 0.9844 \\
\hline $\mathbf{Z n}$ & 1.028 & 0.978 & 2.302 & 0.9793 \\
\hline $\mathbf{C d}$ & 0.956 & 0.9348 & 3.512 & 0.981 \\
\hline $\mathbf{P b}$ & 0.958 & 0.9624 & 3.694 & 0.9878 \\
\hline $\mathbf{F e}$ & 1.337 & 0.9698 & 1.517 & 0.986 \\
\hline
\end{tabular}

\section{Water Purification Tests}

Ten water quality tests, including two replication, EC, TDS, $\mathrm{Ca}^{+2}, \mathrm{Mg}^{+2}$, $\mathrm{Na}^{+1}, \mathrm{NO}_{3}{ }^{-1}, \mathrm{SO}_{4}^{-2}, \mathrm{PH}, \mathrm{Cl}^{-1}$, and turbidity, . The results showed variable ability of purifying of produced filters and this could be caused to their variability in composition of these 
filters. The concentrations of EC, TDS, $\mathrm{Ca}^{+2}, \mathrm{Mg}^{+2}, \mathrm{Na}^{+1}, \mathrm{NO}_{3}^{-1}, \mathrm{SO}_{4}{ }^{-2}, \mathrm{PH}$, $\mathrm{Cl}^{-1}$, and turbidity of allowable concentrations according to Iraqi updated specification No.417 [ 19] and concentrations of raw water were as shown in Table 4.

Fig. 12 showed the variable ability of $\mathrm{CP}$ to remove different contaminations. It had

removed: $99.98 \%$ of turbidity, $78.62 \%$ of EC, $81.61 \%$ of TDS, $73.45 \%$ of $\mathrm{Ca}^{+2}, \quad 9.37 \%$ of $\mathrm{Mg}^{+2}$, $49.69 \%$ of $\mathrm{Na}^{+}, 6.45 \%$ of $\mathrm{Cl}^{-}, 55.63 \%$ of $\mathrm{NO}_{3}{ }^{-}, 1.22 \%$ of $\mathrm{SO}_{4}{ }^{=}$, and $37.54 \%$ of $\mathrm{HCO}_{3}{ }^{-}$. This means it has very good purification properties especially in removing turbidity, EC, TDS, hardness $\left(\mathrm{Ca}^{++}\right), \mathrm{Na}^{+}$, and $\mathrm{NO}_{3}{ }^{-}$due to forming Tridoymite in its final mineralogy.

Table 4. List of tests carried on raw water, allowable concentrations according to the Iraqi Specification and the concentrations in the used raw water.

\begin{tabular}{|c|c|c|}
\hline $\begin{array}{c}\text { Water } \\
\text { quality } \\
\text { parameter }\end{array}$ & $\begin{array}{c}\text { Allowable } \\
\text { concentrations } \\
\text { according to } \\
\text { the Iraqi } \\
\text { specification }\end{array}$ & $\begin{array}{c}\text { Concentrations } \\
\text { in raw water }\end{array}$ \\
\hline $\begin{array}{c}\mathrm{EC}, \\
\mu m / c m\end{array}$ & Not available & 2980 \\
\hline $\mathrm{TDS}, m g / l$ & 1000 & 1740 \\
\hline $\begin{array}{c}\mathrm{Ca}^{+2}, \\
m g / l\end{array}$ & 200 & 678 \\
\hline $\begin{array}{c}\mathrm{Mg}^{+2}, \\
m g / l\end{array}$ & 150 & 331 \\
\hline $\mathrm{Na}^{+1}, m g / l$ & 200 & 131 \\
\hline $\begin{array}{c}\mathrm{NO}_{3}{ }^{-1}, \\
m g /\end{array}$ & 45 & 5.06 \\
\hline $\begin{array}{c}\mathrm{SO}_{4}{ }^{-2}, \\
m g / l\end{array}$ & 400 & 317 \\
\hline $\begin{array}{c}\mathrm{HCO}_{3}{ }^{-1}, \\
m g / l\end{array}$ & Not available & 7.8 \\
\hline $\mathrm{PH}^{-1}, m g / l$ & $6.5-8.5$ & 214 \\
\hline $\begin{array}{c}\mathrm{Turbidity}^{N T U} \\
\mathrm{Tl}^{-1}\end{array}$ & 200 & 123 \\
\hline
\end{tabular}

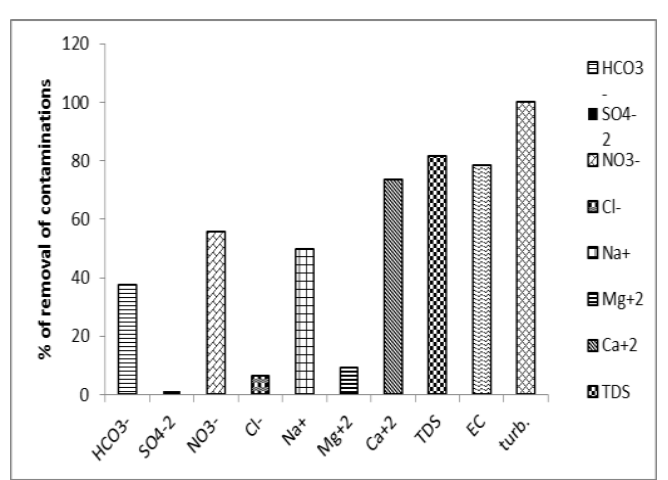

Fig. 12. \% of removal of different contaminations by CP.

\section{Conclusion:}

The following could concluded frome this research:

1. Ceramic water purifier can be produced by using Iraqi Bentonite.

2 . The average hydraulic conductivity of CP is $0.0023 \mathrm{~m} / \mathrm{hr}$.

3 . The ceramic product composites of Tridoymite and Low Cristobalite, which have adsorption properties.

4. The CP could adsorb seven heavy metals, $\mathrm{Mn}, \mathrm{Fe}, \mathrm{Pb}, \mathrm{Cd}, \mathrm{Co}, \mathrm{Cu}$ and $\mathrm{Zn}$, frome their solutions at $1.0 \mathrm{mg} / \mathrm{l}$, and $10.0 \mathrm{mg} / \mathrm{l}$ concentrations.

5. Asorption capacity of $\mathrm{CP}$ seven heavy metals, $\mathrm{Mn}, \mathrm{Fe}, \mathrm{Pb}, \mathrm{Cd}, \mathrm{Co}, \mathrm{Cu}$ and $\mathrm{Zn}$ according to Freundlich model are: $\mathrm{Pb}>\mathrm{Cd}>\mathrm{Cu}>\mathrm{Zn}>\mathrm{Mn}>\mathrm{Co}>\mathrm{Fe}$, and maximum capacity was for $\mathrm{Pb}(3.694$ $\mathrm{mg} / \mathrm{g})$, and minimum was for $\mathrm{Fe}(1.517$ $m g / g$ ). While according to Langmuir model were: $\mathrm{Fe}>\mathrm{Co}>\mathrm{Mn}>\mathrm{Zn}>\mathrm{Pb}>\mathrm{Cd}>\mathrm{Cu}, \quad$ and maximum capacity was for $\mathrm{Fe}(1.337$ $m g / g)$, and minimum was for $\mathrm{Cu}$ $(0.394 \mathrm{mg} / \mathrm{g})$.

6. Purification properties of $\mathrm{CP}$ are removing: 99.98 \% of turbidity, $78.62 \%$ of EC, $81.61 \%$ of TDS, $73.45 \%$ of $\mathrm{Ca}^{+2}, \quad 9.37 \%$ of $\mathrm{Mg}^{+2}$, $49.69 \%$ of $\mathrm{Na}^{+}, 6.45 \%$ of $\mathrm{Cl}^{-}, 55.63 \%$ of $\mathrm{NO}_{3}{ }^{-}, 1.22 \%$ of $\mathrm{SO}_{4}{ }^{-}$, and $37.54 \%$ of $\mathrm{HCO}_{3}{ }^{-}$. 


\section{References:}

1. Al-Bassam, Khaldoun S., Abdul Rahman, Shaima'a M., and Rashid, Sallama Ch., 2011, Cation Exchange Capacity in Iraqi Industrial Montmorillonitic Claystones and Their Use in the Estimation of Montmorillionite Content in the Produced Clay, Jour. Geol.Soc. Iraq, Vol.7, No.3, p. 1 - 17.

2. General Company of Geological Surveying and Mineralization (GCGSM), 2008, Chemical and Physical Specifications of Industrial Extracted Rocks.

3. Grim, R.E., 1968. Clay Mineralogy, 2nd edit. Mc Graw Hill Book Co., N.Y., 596pp

4. Albassam, K.S., et al., 1993, Using Iraqi Porcelanite as Industrial Filters, General Company of Geological Surveying and Mineralization, Internal Report.

5. Albadry, A.H.S., 2000, Scientific Technic for Ceramic Art, 1.st Part : Clay, Al-yarmuke University, $1^{\text {st }}$ edition.

6. Jassim, Sanaa, A.R. , 2010, Evaluation of Water Purifier Cartridge Made of Local Ceramic Materials, Ph.D.Thesis, College of Engineering, Baghdad University.

7. Hamilton, D., 1982, Manual of Pottery and Ceramics, Thames and Hilton Ltd., London. Printed in Hong Kong. ISBN O500 680078.

8. Serry, M.A., and Hanna, S., 1979, Composition and Properties of Some Dolomite Zirconia Refractories, Trans.Br.Ceramic, Soc.Vol.78, No.3.

9. ASTM C373-88, 2006, Standard Test Method for Water Absorption, Bulk Density, Apparent Porosity, and Apparent Specific Gravity of Fired Whiteware Products.
10. Hamil, L., and Bell, F. G., 1986, Ground water resource development, Better Worth, London.

11. Lamb, T.W., and Whitman, R.V., 1969, Soil Mechanics, John Wiley and Sons, Inc., U.S.A.

12. Mohamed, S. N. D., 2005, Assessment of Utilization of Gypsum and Clay from the Fatha Formation in

Darband Bazian Area in Manufacturing of Thermal Insulators, M.Sc. Thesis, College of Science, Baghdad University, Iraq

13. Demirba, E., Kobya, M., Oncel, S., and Sencan, S., 2002, Removal of $\mathrm{Ni}$ (II) from Aqueous Solution by Adsorption onto Hazelnut Shell Activated Carbon, Equilibrium Studies, Bioresource Technology.

14. Cooney, D. O., 1999, Adsorption Design for Wastewater Treatment, Boca Raton, Lewis Publishers.

15. Laidler, K. J., and Meiser, J. H., 1999, Physical Chemistry, 3rd edition, Boston, Houghton Mifflin Company.

16. Bayat, B., 2002, Comparative Study of Adsorption Properties of Turkish Fly Ashes: 1. The Case of Nickel(II), Copper(II), and Zinc(II). Jou. Haz. Mat

17. Dakiky, M., Khamis, M., Manassra, A. and Mer'eb, M., 2002,

Selective Adsorption of Chromium(VI)in Industrial Wastewater Using Low-cost Abundantly Available Adsorbents, Advances in Environmental Research.

18. WHO(World Health Organization), 2006, WHO Guidelines for Drinking Water Quality, $3^{\text {rd }}$ edition. Geneva: World Health Organization. 19. Rayon, W., 1978, Properties of Ceramic Raw Materials, $2^{\text {nd }}$ edition, Pergamon Press, Oxford.

20. Iraqi Standard Specification of Drinking Water No.417, 1974. 


\section{BPL1 انتاج منقيات مياه خزفية مصنعة من البنتونايت العراقي نوع}

حبيب رشبي حبيب*
رياض زهير الزبيبيةي*
سناء عبل الرزاق جاسمث*

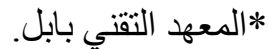

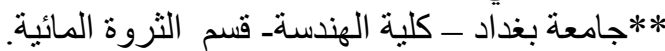

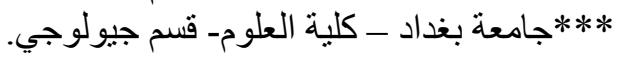

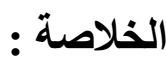

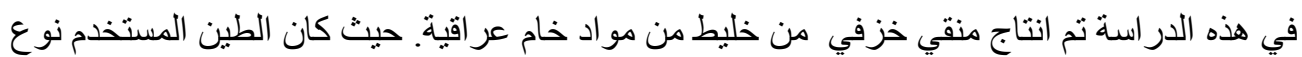

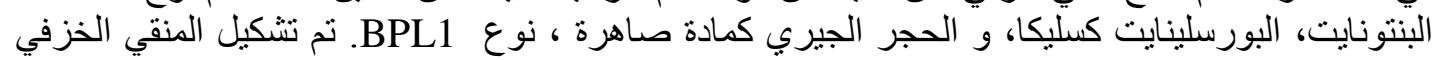

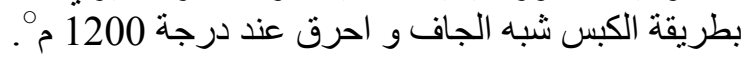

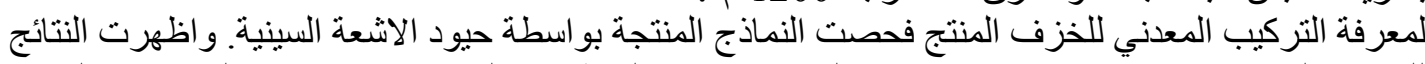

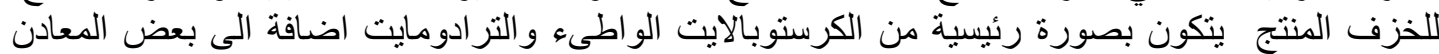

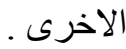
لدر اسة الإيصالية الهيدروليكية للمنقي الخزفي المصنع فقد تم تنفيذ جهاز قياس الايصالية الهيدروليكية ـ. ومن

النتائج تبين ان الايصالية الهيدروليكية للمنقي المنتج للمرشحات المصنعة تساوي 55 مرة بقدر الايصالية

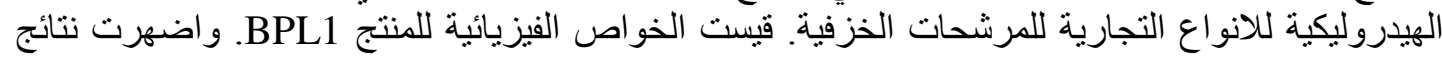

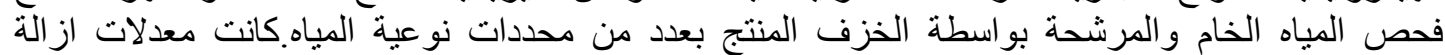

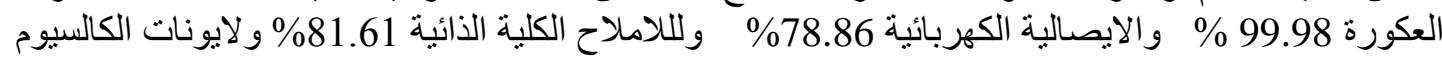

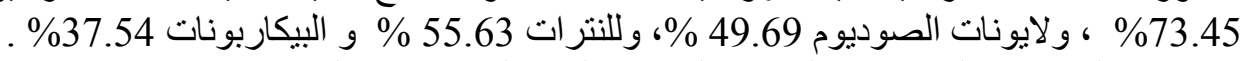
اوضحت النتائج ان المرشحات الخزفية المصنعة لها قابلية ممتازة على امدصاص سبعة من العناصر النقيلة

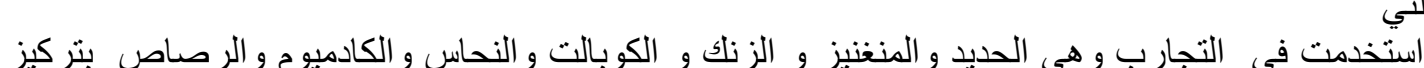

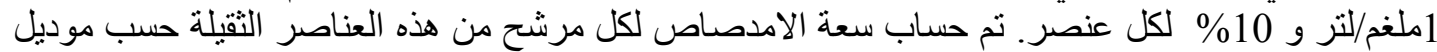
لانكميور وموديل فريو بلجج. وكانت سعة الامدصاص مختلفة لكل من هذه العناصر السبعة الثقيلة. 